\title{
PENGARUH BIAYA BAHAN BAKU, BIAYA TENAGA KERJA LANGSUNG DAN FACTORY OVERHEAD COST TERHADAP PENINGKATAN HASIL PRODUKSI PADA PERUSAHAAN KECIL INDUSTRI TAHU TEMPE DI KOTA BATAM
}

\author{
Baru Harahap ${ }^{1}$, Argo Putra Prima ${ }^{2}$ \\ Dosen Universitas Putera Batam \\ email: baru@puterabatam.ac.id
}

\begin{abstract}
The purpose of this research is to determine the effect of production costs and selling prices on increasing sales profits at PT Shimano Batam. The sample used in this study is financial statements: (1). PT Shimano Batam financial statements before the period 2013 - 2017; (2). The financial statements of PT Shimano Batam that were listed during the period 2013 - 2017; and (3). The financial statements have been audited as of December 31, 2013 - 2017. The results of this study have a significant effect on production costs and selling prices on increasing sales profits at PT Shimano Batam with significant values of 0,000 and 0,000<0,05, respectively. While simultaneous production costs and selling prices have a significant effect on increasing sales profits at PT Shimano Batam with a significant value of $0,000<0,05$.
\end{abstract}

Keywords: production costs, selling prices, sales profits.

\section{PENDAHULUAN}

Persaingan dunia usaha sekarang ini semakin besar, terutama usaha dalam sektor industri. Hal ini ditandai dengan banyak didirikannya usaha didaerahdaerah baik usaha kecil maupun usaha menengah. Pengusaha-pengusaha biasanya mendirikan usaha yang sejenis, karena termotivasi oleh pengusaha yang telah berhasil lebih dahulu memasuki dunia usaha. Hal tersebut menyebabkan persaingan antar pengusaha semakin ketat. Persaingan dapat dihadapi dengan mengelola pengaruh biaya bahan baku, biaya tenaga kerja langsung dan factory overhead cost dengan baik untuk dapat memaksimalkan hasil produksi dan dapat menekan Biaya Bahan Baku.

Usaha Kecil dan Menengah (UKM) mempunyai peran strategis dalam pembangunan ekonomi nasional, oleh karena itu selain berperan dalam pertumbuhan ekonomi dan penyerapan tenaga kerja juga berperan dalam pendistribusian hasil-hasil pembangunan. Dalam sektor, khususnya industri kecil dan menengah termasuk industri kerajinan dan industri rumah tangga perlu dilakukan pembinaan agar menjadi usaha yang efisien dan berkembang.

Pengembangan industri kecil dan menengah dapat dilakukan dengan cara memberikan kemudahan baik dalam permodalan, perijinan maupun pemasaran serta meningkatkan kerja sama dengan industri yang berskala besar melalui pola kemitraan dalam usaha meningkatkan peran dan kedudukannya dalam pembangunan industri.

Pembinaan pengusaha kecil harus lebih diarahkan untuk meningkatkan kemampuan pengusaha kecil . Lemahnya kemampuan manajerial dan SDM ini mengakibatkan pengusaha kecil tidak mampu menjalankan usahanya dengan baik. Manajemen dalam usaha kecil masih tergolong sederhana dan apa adanya.

Produk sebagai output (keluaran) dari proses produksi sangat bergantung pada faktor produksi sebagai input (masukan). Semakin besar jumlah faktor produksi (input) yang masuk dalam proses produksi, semakin besar pula jumlah produk (output) yang dihasilkan(Nasution, 2013). Sedangkan menurut (Swastha, 2015) menyatakan bahwa setiap ada kenaikan input 
(modal, kekayaan alam, tenaga kerja, dan teknologi) maka output (hasil produksi) akan mengalami peningkatan. Akan tetapi, keadaan ini tidak berlaku untuk tenaga kerja. Peningkatan tenaga kerja boleh jadi menyebabkan peningkatan produksi tetapi dapat juga mengakibatkan berkurangnya produksi. Dalam memproduksi barang atau jasa, faktor produksi merupakan hal utama yang perlu diperhatikan. Karena jika faktor produksi tersebut tidak ada, maka proses produksi dalam perusahaan akan terhambat.

Pembelian bahan baku berupa kacang kedelai. Biaya tenaga kerja langsung, yaitu semua balas jasa yang diberikan kepada karyawan pabrik yang manfaatnya dapat diidentifikasikan atau diikuti jejaknya pada produk tertentu yang dihasilkan perusahaan. Biaya tenaga kerja langsung yang dikeluarkan seperti upah persiapan bahan, perendaman, pencucian, penggiling, dimasak, penyaringan, pemisahan, pemberian cuka, Penggumpalan, dan pencetakan. Sedangkan biaya tidak langsung atau biaya overhead pabrik tidak diperhitungkan dalam penghitungan Biaya Bahan Baku karena biaya ini menurut pembuat tahu tempe tidak berpengaruh secara langsung terhadap Biaya Bahan Baku. Biaya yang termasuk biaya overhead pabrik, misalnya biaya perbaikan alat pembuat tahu dan pemeliharaan alat pembuat tahu.

Melihat kondisi diatas, maka diharapkan pembuat tahu dan tempe dapat mengelola Biaya Bahan Bakunya secara optimal sehingga mampu meningkatkan hasil produksi. Peningkatan tersebut diharapkan menambah pendapatan atau keuntungan yang diterima pembuat tahu dan tempe demi keberlanjutan usaha dan perkembangan usaha. Atas dasar pemikiran tersebut, maka peneliti tertarik untuk mengadakan penelitian dengan judul "Pengaruh Biaya Bahan Baku, Biaya Tenaga Kerja Langsung Dan Factory Overhead Cost Terhadap Peningkatan Hasil Produksi Pada Perusahaan Kecil Industri Tahu Tempe di Kota Batam".

\section{TINJAUAN PUSTAKA}

\section{Hasil Produksi}

Menurut (Haryanto, 2012: 15), hasil produksi atau output adalah total barang atau jasa yang dihasilkan oleh unit usaha atau perusahaan. Hasil produksi merupakan keluaran (output) yang diperoleh dari pengelolaan input produksi (sarana produksi atau biasa disebut masukan) dari suatu usaha.

Menurut (Beattie, 2014), produk sebagai output (keluaran) dari proses produksi sangat bergantung pada faktor produksi sebagai input (masukan). Semakin besar jumlah faktor produksi (input) yang masuk dalam proses produksi, semakin besar pula jumlah produk (output) yang dihasilkan.

(Wilson, 2014) mengemukakan bahwa fungsi produksi menjelaskan hubungan antara faktor-faktor produksi dengan hasil produksi. Besarnya jumlah hasil produksi yang dihasilkan tergantung dari penggunaan input-input tersebut. Jumlah hasil produksi dapat ditingkatkan dengan cara meningkatkan penggunaan jumlah input atau sumber daya. Untuk memperoleh hasil yang efisien, produsen dapat melakukan pilihan penggunaan input yang lebih efisien.

Dari pengertian diatas, hasil produksi adalah jumlah barang yang dihasilkan oleh pengolahan faktor-faktor produksi dalam suatu unit usaha. Hasil produksi yang dimaksud dalam penelitian ini adalah jumlah Tahu dan Tempe yang dihasilkan oleh pembuat Tahu dan Tempe dalam sekali proses produksi (dalam waktu satu bulan) diukur dengan satuan dan dikalikan dengan Biaya Tenaga Kerja Langsung Tahu dan Tempe (rupiah).

\section{Biaya Bahan Baku}

Menurut (Nafarin, 2014: 202), bahan baku adalah bahan utama atau bahan pokok dan merupakan komponen utama dari suatu produk. Sedangkan menurut (Mulyadi, 2013: 295), bahan baku merupakan bahan yang membentuk bagian menyeluruh produk jadi. Bahan baku yang diolah dalam perusahaan manufaktur dapat diperoleh dari pembelian lokal, impor atau pengolahan sendiri. Bahan baku merupakan bahan yang membentuk bagian menyeluruh produk jadi. Di dalam memperoleh bahan baku, perusahaan tidak hanya mengeluarkan biaya sejumlah harga beli saja, tetapi juga mengeluarkan biaya-biaya pembelian, pergudangan, dan biaya perolehan lainnya. 
Semua produk pabrikan (manufacturing products) terbuat dari bahan baku langsung dasar. Menurut (Nafarin, 2014: 40), bahan langsung (direct material) adalah semua bahan yang membentuk bagian integral dari barang jadi dan yang dapat dimasukan langsung dalam kalkulasi biaya produk. Bahan baku langsung ini menjadi bagian fisik produk, dan terdapat hubungan langsung antara masukan bahan baku dan keluaran dalam bentuk produk jadi.

Menurut (Pinasih, 2015), biaya bahan baku langsung adalah biaya dari komponenkomponen fisik produk. Biaya bahan baku dapat dibebankan secara langsung kepada produk karena observasi fisik dapat dilakukan untuk mengukur kuantitas yang dikonsumsi oleh setiap produk. Bahan baku yang tidak dapat diidentifikasi secara langsung dengan suatu unit produk jadi disebut bahan baku penolong (indirect material). Bahan baku penolong dimasukkan kedalam biaya overhead pabrik. Biaya bahan baku (direct material cost) adalah biaya semua bahan yang secara fisik dapat diidentifikasi sebagai bagian dari produk jadi dan biasanya merupakan bagian terbesar dari material pembentuk harga pokok produksi (Nasution, 2013: 193).

\section{Biaya Tenaga Kerja Langsung}

Menurut (Sukirno, 2015: 6), tenaga kerja dibedakan menjadi tiga golongan yaitu tenaga kerja kasar, tenaga kerja terampil dan tenaga kerja terdidik. Tenaga kerja kasar adalah tenaga kerja yang tidak berpendidikan atau rendah pendidikannya dan tidak memiliki keahlian dalam suatu bidang pekerjaan. Tenaga kerja terampil adalah tenaga kerja yang memiliki keahlian dari pelatihan atau pengalaman kerja. Sedangkan tenaga kerja tedidik adalah tanaga kerja yang memiliki pendidikan cukup tinggi dan ahli dalam bidang tertentu.

Biaya tenaga kerja adalah harga yang dibebankan untuk penggunaan tenaga pekerja tersebut (Mulyadi, 2013: 343). Biaya tenaga kerja adalah semua biaya yang menyangkut gaji dan upah seluruh pekerja yang secara praktis dapat diidentifikasi. Biaya tenaga kerja adalah semua balas jasa (teken prestasi) yang diberikan oleh perusahaan kepada semua karyawan (Supriyono, 2013: 20). Sesuai dengan fungsi di mana karyawan bekerja, biaya tenaga kerja dapat digolongkan ke dalam biaya tenaga kerja pabrik atau produksi, biaya tenaga kerja pemasaran, biaya tenaga kerja administrasi dan umum. Biaya tenaga kerja untuk fungsi produksi dibagi menjadi dua bagian yaitu:

a. Biaya tenaga kerja langsung, yaitu semua balas jasa yang diberikan kepada karyawan pabrik yang manfaatnya dapat diidentifikasikan atau diikuti jejaknya pada produk tertentu yang dihasilkan perusahaan.

b. Biaya tenaga kerja tidak langsung, yaitu semua balas jasa yang diberikan

c. kepada karyawan pabrik, akan tetapi manfaatnya tidak dapat diidentifikasikan atau diikuti jejaknya pada produk tertentu yang dihasilkan perusahaan.

\section{Penelitian Terdahulu}

Penelitian ini dilakukan tidak terlepas dari hasil penelitian-penelitian terdahulu yang pernah dilakukan sebagai bahan perbandingan dan kajian. Adapun yang menjadi rujukan penelitian terdahulu dari penelitian ini adalah:

1. (Ghaemi \& Nematollahi, 2012), International Journal of Trade, Economics and Finance, Vol. 3, No. 1, February 2012, "Study on the Behavior of Materials, Labor, and Overhead Costs in Manufacturing Companies listed in Tehran Stock Exchange", This research is the kind of practical research and with use of Analyzing information contained in income statements of companies listed in Tehran Stock Exchange for the period 2010 to 2012 is conducted. The aim of this research is determine the causal relationship of sales income and expenses and evaluation of costs stickiness. Costs stickiness means that with activity increase, Costs are increasing faster than when activity decrease and costs decreasing. 
2. (Lasena, 2013), Jurnal EMBA 585, Vol.1 No.3 Juni 2013, Hal. 585-592, ISSN 2303-1174, dalam penelitiannya mengenai Analisis Penentuan Harga Pokok Produksi Pada PT. Dimembe Nyiur Agripro.

3. (Rahman \& Suseno, 2014), Jurnal Akuntansi FE Unsil, Vol. 3, No. 1, Mei 2014 ISSN: 1907-9958, dalam penelitiannya mengenai Pengaruh Biaya Tenaga Kerja Langsung Terhadap Volume Produksi (Studi Kasus Pada Perusahaan Galunggung Raya Block Tasikmalaya).

\section{Kerangka Berfikir}

Berdasarkan uraian diatas, Biaya Bahan Baku langsung dan hasil produksi mempunyai keterkaitan yang ditunjukan dalam bagan sebagai berikut:

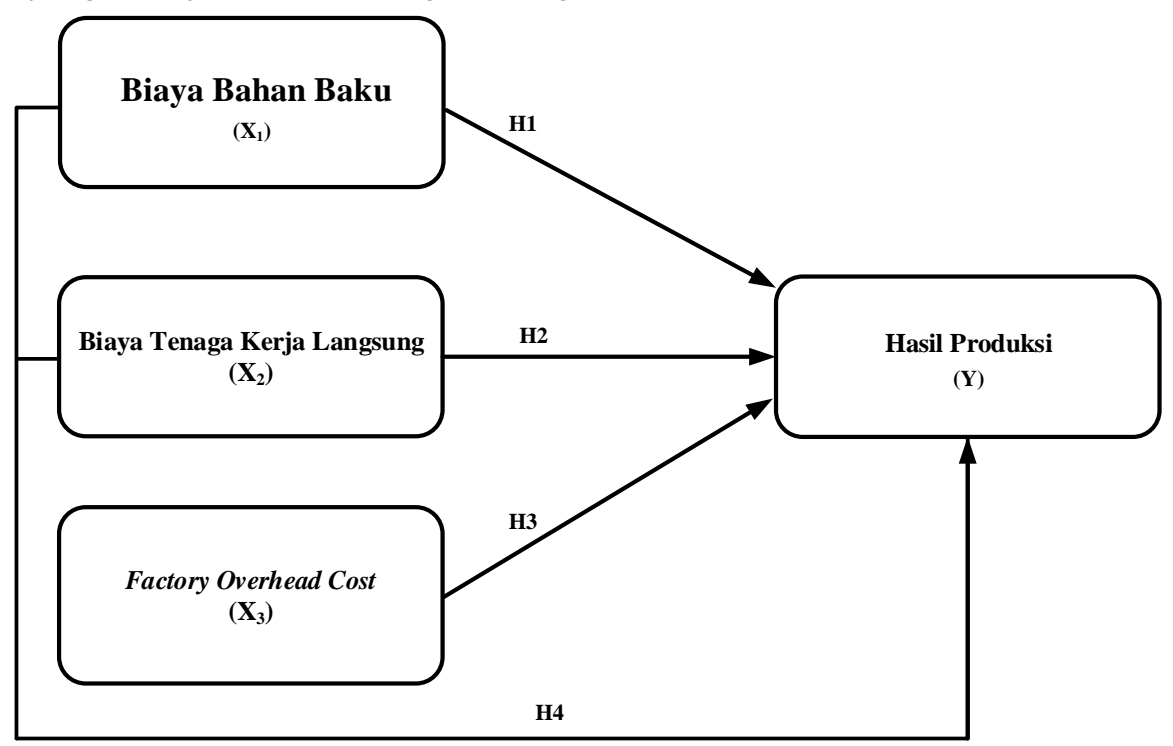

Gambar 1. Kerangka Pemikiran

\section{Hipotesis} hipotesis:

Berdasarkan kerangka pemikiran dalam penelitian ini, maka penulis mengajukan

$\mathrm{H}_{1}$ : Ada pengaruh biaya bahan baku terhadap peningkatan hasil produksi pada perusahaan kecil industri tahu tempe di Kota Batam.

$\mathrm{H}_{2}$ : Ada pengaruh biaya tenaga kerja langsung terhadap peningkatan hasil produksi pada perusahaan kecil industri tahu tempe di Kota Batam.

$\mathrm{H}_{3}$ : Ada pengaruh factory overhead cost terhadap peningkatan hasil produksi pada perusahaan kecil industri tahu tempe di Kota Batam.

$\mathrm{H}_{4}$ : Ada pengaruh biaya bahan baku, biaya tenaga kerja langsung dan factory overhead cost terhadap peningkatan hasil produksi pada perusahaan kecil industri tahu tempe di Kota Batam

\section{METODE}

(Efferin, 2012: 48) mengemukakan bahwa desain penelitian (research design), adalah merupakan framework dari suatu penelitian ilmiah. Desain penelitian yang baik akan menjadi menentukkan keberhasilan serta kualitas dari suatu penelitian ilmiah. Dengan menyusun suatu desain penelitian, peneliti pada dasarnya membuat arahan tentang berbagai hal yang harus dilakukan dalam upaya untuk melakukan suatu penelitian.

Di dalam penelitian kuantitatif ini digunakan dua jenis variabel, yaitu variabel independennya (bebas) adalah Biaya Bahan Baku $\left(\mathrm{X}_{1}\right)$, Biaya Tenaga Kerja Langsung $\left(\mathrm{X}_{2}\right)$ dan Factory Overhead Cost $\left(\mathrm{X}_{3}\right)$ dan variabel dependennya (terikat) adalah Peningkatan Hasil 
Produksi (Y). Penelitian ini bertujuan untuk mengetahui pengaruh antara kedua variabel independen terhadap variabel dependen.

Metode pengambilan sampel dilakukan berdasarkan beberapa alasan dengan teknik yang digunakan yaitu porposive sampling menentukan sampel dengan pertimbangan tertentu. Adapun dengan kriteria penelitian sebagai berikut:

1. Perusahaan kecil industri tahu tempe yang terdaftar sebelum periode 2013 - 2017.

2. Perusahaan yang di listing selama periode 2013 - 2017.

3. Laporan keuangan secara lengkap per 31 Desember periode 2013 - 2017.

Dengan menggunakan metode analisisnya adalah regresi berganda, yaitu suatu Metode yang memperlihatkan hubungan antara satu variabel terikat (dependent variable) dengan beberapa variabel bebas (independent variables). Bentuk matematisnya adalah sebagai berikut (Wibowo, 2012: 27):

$Y_{i=} \beta_{0}+\beta_{1} X_{1 i}+\beta_{2} X_{2 i}+\beta_{3} X_{3 i}+\cdots+k X_{k i}+\varepsilon_{i}$

Model perkiraan regresi linear dapat dinyatakan sebagai berikut:

$Y_{i=} \beta_{0}+\beta_{1} X_{1}+\beta_{2} X_{2}+\beta_{3} X_{3}+\varepsilon_{i} \quad$ Rumus 1. Regresi Linier Berganda

Keterangan :

$\mathrm{Y}=$ Peningkatan Hasil Produksi

$\beta_{0}=$ konstanta

$\beta_{1}=$ Koefisien Regresi Variabel Biaya Bahan Baku $\left(\mathrm{X}_{1}\right)$

$\beta_{2}=$ Koefisien Regresi Variabel Biaya Tenaga Kerja Langsung $\left(\mathrm{X}_{2}\right)$

$\beta_{3}=$ koefisien regresi variabel Factory Overhead Cost $\left(\mathrm{X}_{3}\right)$

$X_{1}=$ Biaya Bahan Baku

$X_{1 i}=$ Biaya Tenaga Kerja Langsung

$X_{2 i}=$ Factory Overhead Cost

$\varepsilon_{i}=$ epsilon (faktor lain)

\section{HASIL DAN PEMBAHASAN}

\section{A. Hasil Uji Asumsi Klasik}

\section{1). Hasil Uji Multikolinieritas}

Uji multikolonieritas bertujuan untuk menguji apakah pada model regresi ditemukan adanya korelasi antar variabel bebas (independen). Model regresi yang baik seharusnya tidak terjadi korelasi diantara variabel independen (Ghozali, 2013:105). Multikolinearitas dapat dilihat dari nilai tolerance dan lawannya yaitu Variance Inflation Factor (VIF). Nilai cutoff yang umum dipakai untuk menunjukkan adanya multikolonieritas adalah nilai Tolerance $\leq 0.10$ atau sama dengan nilai VIF $\geq 10$ (Ghozali, 2013: 106). Berikut ini adalah tabel yang menunjukan hasil uji multikolinieritas. Hasil pengujian multikolinieritas dapat dilihat pada tabel berikut:

Tabel 1. Hasil Uji Multikolinieritas

\begin{tabular}{|c|c|c|c|}
\hline \multirow{2}{*}{ Variabel } & \multicolumn{2}{|c|}{ Collinearity Statistics } & \multirow{2}{*}{ Kesimpulan } \\
\hline & Tolerance & $V I F$ & \\
\hline $\mathrm{X}_{1}$ & 0.517 & 1.933 & Tidak Terjadi Multikolinieritas \\
\hline $\mathrm{X}_{2}$ & 0.370 & 2.701 & Tidak Terjadi Multikolinieritas \\
\hline$X_{3}$ & 0.442 & 2.264 & Tidak Terjadi Multikolinieritas \\
\hline
\end{tabular}

Berdasarkan hasil pengujian multikolinearitas semua variabel diatas memiliki nilai VIF dibawah angka 10 dan nilai tolerance lebih dari 0.1 . Hal ini menunjukkan tidak terjadi multikolinieritas atau hubungan antar variabel independen dalam model regresi tersebut. 


\section{2). Hasil Uji Normalitas}

Uji normalitas dengan menggunakan metode Kolmogorov-Smirnov jika mendekati atau berdistribusi normal dapat dilihat dari nilai Asymp Sig. (2-tailed), yaitu apabila Asymp Sig. (2tailed) > 0,05 maka distribusi data adalah normal dan apabila nilai Asymp Sig. (2-tailed) $<0,05$ maka distibusi data adalah tidak normal. Berdasarkan hasil uji normalitas menunjukkan bahwa nilai Asyimp Sig. (2-tailed) lebih besar dari nilai probabilitas (p) yaitu 0,05 sehingga dapat disimpulkan bahwa data penelitian memiliki distribusi normal.

Tabel 2. One-Sample Kolmogorov-Smirnov Test

One-Sample Kolmogorov-Smirnov Test

\begin{tabular}{|ll|r|}
\hline & & $\begin{array}{r}\text { Unstandardiz } \\
\text { ed Residual }\end{array}$ \\
\hline $\mathrm{N}$ & Mean & 90 \\
Normal Parameters & $0 \mathrm{E}-7$ \\
& Std. & 2.43048869 \\
Most Extreme & Deviation & .068 \\
Differences & Absolute & .057 \\
Kolmogorov-Smirnov Z & Positive & -.068 \\
Asymp. Sig. (2-tailed) & .641 \\
\hline
\end{tabular}

a. Test distribution is Normal.

b. Calculated from data.

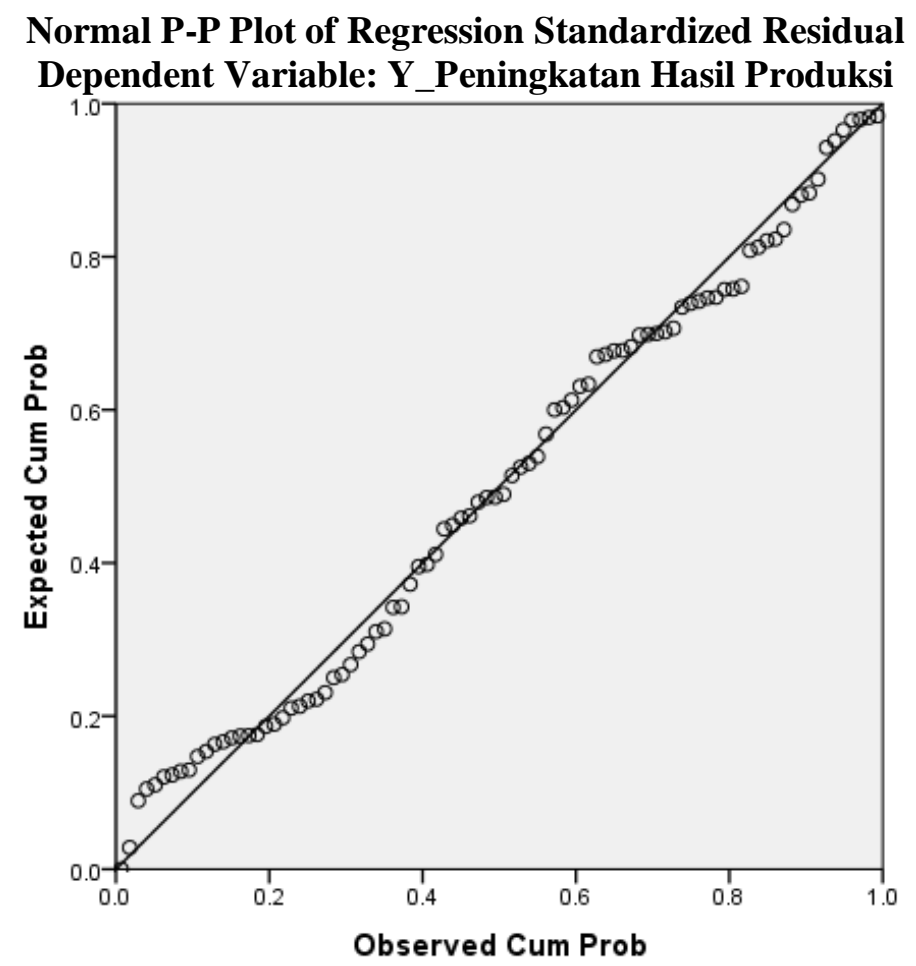

Gambar 2. Hasil Uji Normalitas

Dari hasil pengujian normalitas di atas, menunjukkan titik-titik menyebar di sekitar garis diagonal untuk variabel dependen Peningkatan Hasil Produksi. Penyebaran tersebut mengikuti arah garis diagonal. Hal ini menunjukkan bahwa data tersebar dengan normal dan model regresi tersebut layak untuk dipakai.

3). Hasil Uji Heteroskedastisitas

Hasil pengujian heteroskedastisitas dapat dilihat pada gambar sebagai berikut: 


\section{Scatterplot}

\section{Dependent Variable: Y_Peningkatan Hasil Produksi}

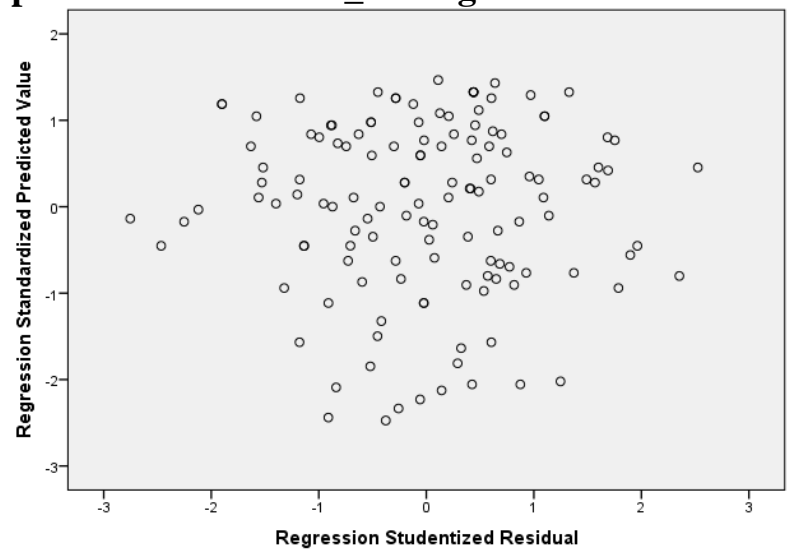

Gambar 3 Hasil Uji Heteroskedastisitas

Dari gambar di atas, dapat dilihat bahwa titik-titik menyebar di atas dan dibawah angka nol pada sumbu $\mathrm{Y}$ dan tidak membentuk pola yang jelas sehingga tidak terjadi masalah heteroskedastisitas.

\section{B. Hasil Uji Hipotesis}

1). Analisis Regresi Berganda (Multiple Regression Linear)

Untuk uji hipotesis ini digunakan analisis regresi berganda (Multiple Regression Linear).

Tabel 3. Hasil Uji Regrsi Linier Berganda

\begin{tabular}{llll}
\hline \multicolumn{3}{c}{ Dependent Variable: Peningkatan Hasil Produksi $(Y)$} \\
\hline \multicolumn{1}{c}{ Variabel } & $\begin{array}{c}\text { Unstandardized } \\
\text { Coefficient }\end{array}$ & & \\
\cline { 2 - 3 } & $\mathbf{B}$ & $\mathbf{1}$ & \multicolumn{1}{c}{ Sig. } \\
\hline (Constant) & $\mathbf{4 . 2 4 6}$ & $\mathbf{6 . 4 0 9}$ & $\mathbf{. 0 0 0}$ \\
Biaya Bahan Baku $\left(\mathrm{X}_{1}\right)$ & $\mathbf{0 . 2 0 9}$ & $\mathbf{4 . 1 9 6}$ & $\mathbf{. 0 0 0}$ \\
Biaya Tenaga Kerja Langsung $\left(\mathrm{X}_{2}\right)$ & $\mathbf{0 . 2 0 3}$ & $\mathbf{3 . 0 0 4}$ & $\mathbf{. 0 0 3}$ \\
Factory Overhead Cost $\left(\mathrm{X}_{3}\right)$ & $\mathbf{0 . 1 1 1}$ & $\mathbf{2 . 1 0 4}$ & $\mathbf{. 0 3 8}$ \\
\hline
\end{tabular}

Persamaan regresi dan hasil pengujian hipotesis adalah sebagai berikut:

$$
\mathrm{Y}=4.246+0.209 \mathrm{X}_{1}+0.203 \mathrm{X}_{2}+0.111 \mathrm{X}_{3}+e
$$

Dari persamaan diatas dapat disimpulkan bahwa setiap 1 skor Biaya Bahan Baku $\left(\mathrm{X}_{1}\right)$ bertambah dengan satu-satuan maka akan mempengaruhi Y_Peningkatan Hasil Produksi sebesar 0.209 (20.90\%), setiap 1 skor Biaya Tenaga Kerja Langsung $\left(X_{2}\right)$ bertambah maka akan mempengaruhi Y_Peningkatan Hasil Produksi sebesar $\mathbf{0 . 2 0 3}$ (20.30\%), dan setiap 1 skor Factory Overhead Cost $\left(\mathrm{X}_{3}\right)$ bertambah maka akan mempengaruhi Y_Peningkatan Hasil Produksi sebesar $\mathbf{0 . 1 1 1}$ (11.10\%), selebihnya di pengaruhui oleh faktor lain.

\section{2). Hasil Uji t}

Hasil uji t dapat dilihat pada tabel berikut:

Tabel 4. Hasil Uji t

\begin{tabular}{llrrr}
\hline \multicolumn{4}{c}{ Dependent Variable: Peningkatan Hasil Produksi (Y) } \\
\hline \multirow{2}{*}{ Variabel } & \multicolumn{2}{c}{$\begin{array}{c}\text { Unstandardized } \\
\text { Coefficient }\end{array}$} & & Kesimpulan \\
\cline { 2 - 4 } & $\mathbf{B}$ & t & Sig. & \\
\hline (Constant) & & $\mathbf{6 . 4 0 9}$ & $\mathbf{0 . 0 0 0}$ & Signifikan \\
Biaya Bahan Baku $\left(\mathrm{X}_{1}\right)$ & $\mathbf{0 . 3 7 8}$ & $\mathbf{4 . 1 9 6}$ & $\mathbf{0 . 0 0 0}$ & Signifikan \\
Biaya Tenaga Kerja Langsung $\left(\mathrm{X}_{2}\right)$ & $\mathbf{0 . 3 2 0}$ & $\mathbf{3 . 0 0 4}$ & $\mathbf{0 . 0 0 3}$ & Signifikan \\
\hline
\end{tabular}


Factory Overhead Cost $\left(\mathrm{X}_{3}\right)$

$0.205 \quad 2.104 \quad 0.038$

Signifikan

a. Hasil Pengujian Biaya Bahan Baku $\left(\mathrm{X}_{1}\right)$ Terhadap Peningkatan Hasil Produksi (Y)

Hasil dari terhadap variabel dependen Peningkatan Hasil Produksi yang diukur dengan Y_Peningkatan Hasil Produksi sebesar 0.000 dan nilai koefisien sebesar 0.378 (37.8\%). Nilai probabilitas yang kurang dari 0.05 menunjukkan bahwa Biaya Bahan Baku berpengaruh signifikan Tabel 4 di atas menunjukkan bahwa nilai probalitas Biaya Bahan Baku terhadap Peningkatan Hasil Produksi. Nilai koefisien 0.378 (37.8\%) menunjukkan arah pengaruh positif dari Biaya Bahan Baku.

\section{b. Hasil Pengujian Biaya Tenaga Kerja Langsung $\left(\mathbf{X}_{2}\right)$ Terhadap Peningkatan Hasil Produksi (Y)}

Hasil dari Tabel 4 di atas menunjukkan bahwa nilai probalitas Biaya Tenaga Kerja Langsung terhadap variabel dependen Peningkatan Hasil Produksi yang diukur dengan Y_Peningkatan Hasil Produksi sebesar 0.003 dan nilai koefisien sebesar 0.205 (20.5\%). Nilai probabilitas yang kurang dari 0.05 menunjukkan bahwa Biaya Tenaga Kerja Langsung berpengaruh signifikan terhadap Peningkatan Hasil Produksi. Nilai koefisien 0.205 (20.5\%) menunjukkan arah pengaruh positif dari Biaya Tenaga Kerja Langsung.

\section{c. Hasil Pengujian Factory Overhead Cost $\left(\mathbf{X}_{3}\right)$ Terhadap Peningkatan Hasil Produksi (Y)}

Hasil dari Tabel 4 di atas menunjukkan bahwa nilai probalitas Factory Overhead Cost terhadap variabel dependen Peningkatan Hasil Produksi yang diukur dengan Y_Peningkatan Hasil Produksi sebesar 0.038 dan nilai koefisien sebesar $\mathbf{0 . 3 2 0}$ (32.0\%). Nilai probabilitas yang kurang dari 0.05 menunjukkan bahwa Factory Overhead Cost berpengaruh signifikan terhadap Peningkatan Hasil Produksi. Nilai koefisien 0.320 (32.0\%) menunjukkan arah pengaruh positif dari Factory Overhead Cost.

\section{3). Hasil Uji F}

Hasil pengujian F dapat dilihat pada tabel berikut:

Tabel 5. Hasil Uji F

\begin{tabular}{cccc}
\hline Variabel Dependen & F & Sig. & Kesimpulan \\
\hline Y_Peningkatan Hasil Produksi & $\mathbf{5 0 . 8 5 9}$ & $\mathbf{. 0 0 0}^{\mathbf{b}}$ & Signifikan \\
\hline
\end{tabular}

c. Hasil Pengujian Variabel Biaya Bahan Baku $\left(\mathbf{X}_{1}\right)$, Biaya Tenaga Kerja Langsung $\left(\mathbf{X}_{2}\right)$ dan Factory Overhead Cost $\left(\mathrm{X}_{3}\right)$ secara simultan Terhadap Peningkatan Hasil Produksi (Y)

Berdasarkan hasil uji $\mathrm{F}$, nilai $\mathrm{F}$ yang diperoleh untuk variabel dependen Peningkatan Hasil Produksi sebesar 50.859 dengan nilai probabilitasnya 0.000. Karena nilai signifikansi kurang dari 0.05 maka dapat disimpulkan bahwa model regresi tersebut dapat digunakan untuk memprediksi Peningkatan Hasil Produksi.

\section{4). Hasil Uji Koefisien Determinasi $\left(\mathbf{R}^{2}\right)$}

Tabel 6. Hasil Uji Koefisien Determinasi $\left(\mathrm{R}^{2}\right)$

\begin{tabular}{cccc}
\hline Variabel Dependen & $\boldsymbol{R}$ & $\boldsymbol{R}$ Square & Adjusted $\boldsymbol{R}$ Square \\
\hline $\begin{array}{c}\text { Y_Peningkatan Hasil } \\
\text { Produksi }\end{array}$ & $\mathbf{8 0 . 0 \%}$ & $\mathbf{6 4 . 0 \%}$ & $\mathbf{6 2 . 7 0 \%}$ \\
\hline
\end{tabular}

Hasil pengujian menunjukkan bahwa nilai Adjusted $R$ Square $\left(\mathrm{R}^{2}\right)$ untuk model penelitian penulis adalah sebesar 62.70\%. Nilai Adjusted $R$ Square $\left(\mathrm{R}^{2}\right)$ sebesar $\mathbf{6 2 . 7 0 \%}$ ini mengindikasikan bahwa variabel independen dapat menjelaskan variabel dependen sebesar 
62.70\%, sedangkan $\mathbf{3 7 . 3 0 \%}$ lainnya dijelaskan oleh faktor lain yang tidak terdapat dalam model.

\section{SIMPULAN}

Berdasarkan hasil penelitian pada bab-bab sebelumnya, menunjukkan bahwa:

1. Biaya Bahan Baku secara parsial berpengaruh signifikan terhadap Peningkatan Hasil Produksi. Hal ini mungkin disebabkan nilai persediaan pada setiap perusahaan nilai tidak tetap sehingga modal kerja perusahaan juga sering berubah sehingga Peningkatan Hasil Produksi juga sering mengalami perubahan.

2. Biaya Tenaga Kerja Langsung secara parsial berpengaruh signifikan terhadap Peningkatan Hasil Produksi. Hal ini mungkin disebabkan rata-rata perusahaan sampel melaksanakan penagihan piutangnya dengan lancar sehingga modal kerja perusahaan meningkat dan meningkatkan Peningkatan Hasil Produksi.

3. Factory Overhead Cost secara parsial berpengaruh signifikan terhadap Peningkatan Hasil Produksi. Hal ini mungkin disebabkan rata-rata perusahaan sampel melaksanakan biaya overhead pabrik dengan lancar sehingga modal kerja perusahaan meningkat dan meningkatkan Peningkatan Hasil Produksi.

4. Biaya Bahan Baku, Biaya Tenaga Kerja Langsung dan Factory Overhead Cost secara simultan berpengaruh signifikan terhadap Peningkatan Hasil Produksi.

\section{SARAN}

Adapun rekomendasi yang dapat disarankan penulis untuk penelitian selanjutnya adalah:

1. Penelitian selanjutnya diharapkan menambahkan data dengan memperluas tahun penelitian.

2. Penelitian selanjutnya diharapkan menambahkan variabel lain guna untuk menambahkan tingkat determinasi model penelitian seperti siklus konversi kas, quick ratio, ukuran perusahaan, tingkat pertumbuhan, tingkat perputaran aset, tingkat perputaran penjualan dan variabel lainnya.

\section{UCAPAN TERIMA KASIH}

Terima kasih kepada Kemeristekdikti sebagai pemberi dana dalam penelitian ini sehingga penelitian ini dapat terlaksana dengan baik. Terima kasih kepada Koperasi Padjajaran yang terletak di Perumahan Sari Padjajaran Tembesi, Kecamatan Sagulung, Pabrik Tahu dan Tempe di Bengkong yang menjadi objek penelitian penulis

\section{DAFTAR PUSTAKA}

Beattie, B. R. (2014). Ekonomi Produksi. (G. U. Press, Ed.). Yogyakarta: Salemba Empat.

Ghaemi. (2012). Study on the Behavior of Materials, Labor, and Overhead Costs in Manufacturing Companies listed in Tehran Stock Exchange. International Journal of Trade, Economics and Finance, 3.

Lasena. (2013). Analisis Penentuan Harga Pokok Produksi Pada PT. Dimembe Nyiur Agripro. Jurnal EMBA, 1 No.3, 585-592.

Mulyadi. (2013). Akuntansi Biaya. Yogyakarta: Aditya Media.

Nafarin. (2014). Penganggaran Perusahaan. Jakarta: Salemba Empat.

Sugiyono. (2012). Metode Penelitian Kuantitatif Kualitatif dan R\&D. Bandung: Alfabeta.

Sukirno, S. (2015). Mikro Ekonomi Teori Pengantar. Jakarta: PT Raja Grafindo Persada.

Supriyono, R. . (2013). Akuntansi Biaya. Yogyakarta: BPEE.

Suseno, R. (2014). Pengaruh Biaya Tenaga Kerja Langsung Terhadap Volume Produksi (Studi Kasus Pada Perusahaan Galunggung Raya Block Tasikmalaya). Jurnal Akuntansi FE Unsil, Volume $3 \mathrm{~N}$.

Wibowo. (2012). Manajemen Kierja. Jakarta: Rajawali Pers. 